\title{
Pengaruh Pemberian Nutrisi Phaseolus radiatus L. Terhadap Tingkat Kepadatan Spermatozoa Mus musculus L.
}

\author{
ANASTASIA A. BASIR ${ }^{1}$, MUNIF S. HASSAN ${ }^{1}$, THEOPHILLUS BURANDA ${ }^{1}$, \\ EDDYMAN W. FERIAL ${ }^{1}$ \\ ${ }^{1}$ Jurusan Biologi, Fakultas Matematika dan Ilmu Pengetahuan Alam, Universitas Hasanuddin \\ Jl. Perintis Kemerdekaan Km.10 Makassar, 90245 \\ email: anastasia.basir@gmail.com
}

\begin{abstract}
Research about the effect of greenpeal sprout Phaseolus radiatus L. on the spermatozoa density of Mus musculus L. has been done. The purpose of this research was to know the effect of greenpeal sprout Phaseolus radiatus L. on the spermatozoa density of Mus musculus L. Mice is feeded with greenpeal sprout for 21 days. The sperm is collected from cauda of epididimis diluted physiological solution and counted using haemocytometer.

The result showed that micefeeding with greenpeal sprout could increase the density of its spermatozoa. It showed from increase the density of its spermatozoa from 11,05 million/cc sperm in control group become 11,78 million/cc sperm in treatment group by use of $\mathrm{T}$ test. Fidelity guarantee 95 percent explain that there are positive correlation and significant.
\end{abstract}

Keywords: Greenpeal sprout, Mus musculus L., Phaseolus radiatus L., Spermatozoa

\section{PENDAHULUAN}

Indonesia adalah salah satu negara yang memiliki sumber daya alam berupa lahan yang relatif cukup luas dan subur. Dengan iklim, suhu dan kelembaban yang cocok untuk kebutuhan pertumbuhan tanaman pangan pokok, maka hampir seluruh tanaman pangan pokok tersebut (biji-bijian, umbi-umbian dan kacang-kacangan asli Indonesia) dapat tumbuh dengan relatif baik (Plantus, 2008).

Pertambahan penduduk Indonesia berdampak terhadap peningkatan kebutuhan gizi khususnya bahan-bahan alamiah untuk meningkatkan mutu kesehatan sumber asupan gizi terbaik tentu saja berasal dari bahan alami yang merupakan tanaman pangan pokok seperti tanaman kacang-kacangan. Tanaman kacangkacangan termasuk dalam kelas Dicotyledoneae. Diperkirakan sekitar 11.500 jenis yang terbagi ke dalam 500 marga. Banyak jenis tanaman kacangkacangan yang dapat dikonsumsi oleh masyarakat Indonesia di antaranya adalah kacang hijau Phaseolus radiatus L. kacang merah Phaseolus vulgaris, L. kacang kedelai Soja max, L. (Tjitrosoepomo, 2002). Infertilitas merupakan salah satu gangguan dalam kesehatan reproduksi. Infertilitas didefinisikan sebagai ketidakmampuan untuk menghasilkan konsepsi setelah hubungan teratur tanpa menggunakan alat kontrasepsi setelah satu tahun (Rowe, dkk, 2000). Sebanyak $30 \%$ penyebab infertilitas adalah kualitas spermatozoa yang abnormal (Johnson, 2003). Kualitas spermatozoa dalam air mani (semen) ditentukan oleh jumlah, motilitas, dan morfologi (normal atau abnormal) (World Health Organization, 1999). Kontrol hormonal yang dilakukan oleh otak berpengaruh baik secara langsung maupun tidak langsung terhadap fungsi reproduksi. Untuk menghasilkan hormon diperlukan gizi. Kecambah kacang hijau / taoge merupakan sayuran tunas yang sangat kaya akan zat gizi, tauge mengandung kalsium, potasium, besi, fosfor, seng, asam folat, vitamin $\mathrm{C}$, vitamin $\mathrm{B}_{2}$ dan Vitamin E (Sutomo, 2007).

Penelitian menunjukkan Vitamin E merupakan antioksidan yang berperan dalam meningkatkan kesuburan dengan melindungi spermatozoa dari kerusakan akibat radikal bebas (Gsianturi, 2003). Dengan melihat kandungan gizi pada taoge perlu dilakukan penelitian mengenai pengaruh pemberian taoge terhadap jumlah spermatozoa mencit Mus musculus.

\section{METODE}

Pemeliharaan Hewan Uji. Hewan uji yang digunakan adalah mencit M. Musculus L. jantan 
dewasa dengan umur 8-10 minggu dan berat badan rata-rata 23-29 gram sebanyak 8 ekor. Hewan uji ditempatkan di dalam 2 kandang, masing-masing kandang 4 ekor. Kandang berbentuk kotak, terbuat dari bahan fiber dengan ukuran $35 \mathrm{~cm} \times 20 \mathrm{~cm} \times 17 \mathrm{~cm}$, kemudian diberi alas berupa serbuk kayu secukupnya, yang dibersihkan setiap 2 kali seminggu. Kotak tersebut diberi tutup yang terbuat dari besi untuk tempat makanan dan botol minuman. 8 ekor mencit tersebut diadaptasikan pada tempat dan kondisi yang homogen (temperatur, suhu) selama 7 hari sebelum perlakuan. Selama adaptasi, 8 ekor mencit $M$. Musculus diberikan pakan AD2 dan air PAM.

Pengolahan Bahan Kecambah Kacang Hijau Phaseolus radiatus L. Kacang hijau Phaseolus radiatus L. direndam dalam air selama satu hari. Kemudian disebarkan di atas nampan plastik yang telah dilapisi oleh kertas koran bekas yang telah diberi air sebagai substrat untuk menjaga kelembaban agar kacang hijau tidak busuk. Setiap hari disiram dengan air sebanyak 4-5 kali. Perkecambahan dilakukan selama 2 hari hingga mencapai panjang $2 \mathrm{~cm}$.

Pembuatan Pelet Taoge. Kecambah kacang hijau Phaseolus radiatus L. yang diberikan selama perlakuan pada mencit berupa pelet. Tauge yang telah dikecambahkan ditempatkan di dalam nampan kemudian dijemur di bawah sinar matahari hingga kering. ditumbuk dengan menggunakan lumpang porselin hingga halus, dicampurkan dengan pakan AD2 sebagai perekat dengan perbandingan kecambah kacang hijau Phaseolus radiatus dan AD2 adalah 3:1.

Pemberian Nutrisi Pelet Taoge. Perlakuan hewan uji mencit $M$. musculus dibagi menjadi 2 kelompok. Kelompok I sebagai kontrol, mencit M. musculus diberikan pakan AD2 dan air PAM dua kali sehari (pagi dan sore) setiap hari, selama 21 hari. Kelompok II sebagai perlakuan, yaitu diberikan kecambah kacang hijau Phaseolus radiatus L. yang berupa pelet sebanyak 20-30 gram dan air PAM dua kali sehari (pagi dan sore) setiap hari, selama 21 hari.

Pengeluaran Spermatozoa Mencit Mus musculus L. Pengambilan spermatozoa mencit dilakukan dengan pembedahan. Sebelum dibedah, mencit dinarkose dengan menggunakan eter. Bagian abdominal dibedah, lalu diambil salah satu testis, kemudian spermatozoa diperoleh dari bagian cauda epididimis. Epididimis dibersihkan dengan alkohol 70\%, kemudian dimasukkan ke dalam gelas arloji yang berisi $1 \mathrm{ml} \mathrm{NaCl}$ fisiologis, dipotongpotong dengan gunting kecil hingga halus dan diaduk dengan batang pengaduk, hingga membentuk suspensi spermatozoa. Suspensi spermatozoa pada setiap hewan uji mencit ditempatkan pada botol sampel yang berbedabeda.

Pengamatan Tingkat Kepadatan Spermatozoa Mencit Mus musculus L. Penghitungan tingkat kepadatan spermatozoa dilakukan dengan cara, suspensi sperma yang telah ditempatkan pada botol sampel diambil dengan menggunakan pipet tetes, kemudian diteteskan pada haemocytometer, ditutup dengan kaca penutup, kemudian diamati di bawah mikroskop dengan perbesaran 400 kali. Hasil penghitungan merupakan tingkat kepadatan spermatozoa dalam $10^{4} \mathrm{sel} / \mathrm{ml}$ suspensi spermatozoa.

Analisis Data. Analisis spermatozoa dilakukan dengan membandingkan jumlah spermatozoa dari 2 perlakuan, yaitu (1) 4 ekor mencit tanpa perlakuan/kontrol dan (2) 4 ekor mencit yang diberikan tauge secara teratur setiap hari selama 21 hari. Hasil studi kasus-kontrol yaitu dengan menggunakan analisis Uji T untuk melihat ada atau tidaknya pengaruh pemberian nutrisi kecambah kacang hijau Phaseolus radiatus L. terhadap tingkat kepadatan spermatozoa mencit M. musculus L.

\section{HASIL}

Karakteristik Sampel. Dari Tabel 1 terlihat bahwa pemberian nutrisi taoge memberikan pengaruh terhadap peningkatan tingkat kepadatan spermatozoa mencit M. musculus L. Terjadi peningkatan rata-rata tingkat kepadatan dari 11,05 juta/cc sperma pada kelompok kontrol menjadi 11,78 juta/cc sperma pada kelompok perlakuan sehingga dari uji statistik dengan nilai a 0,05 menyatakan terdapat korelasi yang bersifat positif dan signifikan artinya ada pengaruh antara pemberian nutrisi kecambah kacang hijau Phaseolus radiatus L. terhadap tingkat kepadatan spermatozoa mencit $M$. Musculus L. 
Tabel 1. Tingkat kepadatan spermatozoa mencit M. musculus L. pada kelompok kontrol dan perlakuan (juta/cc sperma)

\begin{tabular}{|c|c|c|c|c|c|c|c|}
\hline & \multicolumn{5}{|c|}{ Ulangan } & \multirow[b]{2}{*}{ Rata-Rata } & \multirow[b]{2}{*}{$\mathrm{T}$ hitung \pm Std } \\
\hline & I & II & III & IV & $\Sigma$ & & \\
\hline Kontrol & 9,9 & 10,8 & 11,3 & 12,2 & 44,2 & 11,05 & $5,64 \pm 0,96$ \\
\hline Perlakuan & 11 & 11,3 & 12 & 12,8 & 47,1 & $11,775 *$ & $5,64 \pm 0,80$ \\
\hline
\end{tabular}

*) Berbeda nyata $\alpha 0,05$

\section{PEMBAHASAN}

Hasil penelitian menunjukkan bahwa tingkat kepadatan spermatozoa mencit $M$. musculus L. mengalami peningkatan pada kelompok perlakuan dibandingkan dengan kelompok kontrol. Jumlah keseluruhan spermatozoa pada kelompok kontrol yaitu 44,2 juta/cc sperma sedangkan pada kelompok perlakuan yaitu 47,1 juta/cc sperma Secara statistik dengan $\alpha 0,05$ dan hasil pengamatan menunjukkan bahwa ada pengaruh pemberian nutrisi kecambah kacang hijau Phaseolus radiatus L. terhadap tingkat kepadatan spermatozoa mencit M. musculus L. Hal ini mungkin disebabkan oleh vitamin $\mathrm{E}$ yang terkandung dalam taoge yang dapat meningkatkan kesuburan dengan melindungi spermatozoa dari karusakan akibat radikal bebas sehingga akan terjadi peningkatan produksi spermatozoa mencit $M$. musculus L.

Kecambah kacang hijau Phaseolus radiatus $\mathrm{L}$. mengandung vitamin dan mineral yang berguna apabila dikonsumsi. Dalam hal fertilitas kandungan taoge yang paling berperan yaitu vitamin $\mathrm{E}$ yang merupakan antioksidan yang dapat melindungi sel dari serangan radikal bebas. Berdasarkan hasil penelitian Frank M. Painter (2004) menyatakan bahwa pemberian $600 \mathrm{mg} /$ hari vitamin $\mathrm{E}$ dapat memperbaiki fungsi sperma oleh karena itu dapat mempertinggi penetrasi sperma terhadap sel telur secara in vitro, serta pemberian vitamin E pada 9 orang dengan jumlah sperma rendah selama 6 bulan terbukti dapat meningkatkan motilitas sperma dan persentase keseluruhan sperma normal secara signifikan. Menurut Kessopoulou and colleagues (2002) yang telah melakukan penelitian pada 30 pria yang memiliki fertilitas rendah yang dibagi menjadi 2 kelompok, satu kelompok diberikan $600 \mathrm{mg}$ vitamin $\mathrm{E}$ sedangkan kelompok yang lain diberi placebo. Setelah satu bulan perlakuan diperoleh hasil bahwa potensi sperma dapat diperbaiki dengan vitamin E dapat diketahui setelah pemberian vitamin E tersebut. Menurut Saudi Arabia College (2002) yang telah melakukan penelitian pada lebih dari 100 pasangan suami istri yang tidak dapat hamil disebabkan karena fertilitas rendah pada pria. Setengah dari kelompok ini pria diberikan vitamin E setiap hari dan setengah yang lain diberi placebo. Setelah perlakuan, terbukti bahwa lebih dari 20 $\%$ kelompok vitamin E sukses hamil daripada fertilisasi secara in vitro.

Vitamin E yang terdapat pada kecambah kacang hijau Phaseolus radiatus L. dapat berpengaruh terhadap tingkat kepadatan spermatozoa mencit $M$. musculus L. terjadi karena adanya kontrol reproduksi yang berhubungan dengan sistem hormon. Hormon yang paling berperan dalam sistem reproduksi jantan adalah testosteron, FSH, dan LH. Kontrol hormonal ini dimulai pada saat Gonodotropin Releasing Hormon dibebaskan dari hipotalamus pada otak, kemudian melalui kelenjar pituitari serta adanya rangsangan sehingga dapat dibebaskan Luteinizing Hormon (LH) dan Follicle Stimulating Hormon (FSH) melalui sirkulasi pada testis. LH dan FSH dirangsang oleh sekresi testosteron dari sel Leydig dan estradiol dari 
sel Sertoli. Hormon steroid ini bertanggung jawab menghasilkan libido dan merangsang produksi gamet yang akan menghasilkan spermatozoa. Vitamin E merupakan antioksidan yang dapat melindungi spermatozoa dari berbagai kerusakan akibat serangan radikal bebas, sehingga dengan adanya vitamin $\mathrm{E}$ di dalam tauge maka spermatozoa yang dihasilkan jumlahnya akan semakin banyak karena ada kemungkinan vitamin $\mathrm{E}$ tersebut yang akan melindungi spermatozoa dari berbagai kerusakan.

\section{KESIMPULAN}

Pemberian nutrisi kecambah kacang hijau Phaseolus radiatus L. pada Mus musculus L. meningkatkan kepadatan spermatozoa sebesar 11,05 juta/cc sperma (kontrol) dan 11,78 juta/ cc sperma (perlakuan). Hasil uji T pada tingkat kepercayaan $95 \%$ menyatakan terdapat korelasi yang bersifat positif dan signifikan.

\section{DAFTAR PUSTAKA}

Franken DR dan Thinus FK. 2004. What is a Normal Spermatozoon dalam Thinus FK, Daniel RF. (Editor). Atlas of Human Sperm Morphology Evaluation. UK: Taylor and Francis.

Johnson JV. 2003. Infertility. dalam Scott JR, Gibbs RS, Karlan BY, Haney AF (editor). Danforth's Obstetrics and Gynecology. Edisi ke-9. USA: Lippincott Williams and Wilkins.

Plantus. 2008. Budidaya Kedelai Kemitraan Terpadu. http://anekaplanta.com. Diakses 24 Januari 2008.

Tjitrosoepomo G. 2002. Taksonomi Tumbuhan. Yogyakarta: UGM. 